\title{
Peran Guru Dalam Menerapkan Kebersihan Diri Pada Anak di TK Negeri Pembina Keliling Danau
}

\author{
Penia Lisa Ogemi ${ }^{1}$, Delfi Eliza ${ }^{2}$ \\ ${ }^{1,2}$ Universitas Negeri Padang
}

\begin{tabular}{l}
\hline Article Info \\
\hline Article history: \\
Received 08 Desember 2021 \\
Publish 02 Januari 2022
\end{tabular}

Keywords:

The role of the teacher

Personal hygiene

Early childhood

\section{Info Artikel}

Article history:

Diterima 08 Desember 2021

Publis 08 Desember 2021

\begin{abstract}
Cleanliness is a very important thing to pay attention to, especially personal hygiene in early childhood. Because at an early age children experience a process of rapid growth and development, cleanliness is the main thing that must be considered because children are very susceptible to disease. This requires teachers to be able to apply personal hygiene to children. This study aims to describe the teacher's role in implementing personal hygiene in children. The Pembina Keliling Danau State Kindergarten became the research subject, namely one principal and seven teachers. The use of qualitative analysis in this study with observation, interviews and documentation techniques as data collection. The result of the research is that the teacher motivates children in terms of maintaining cleanliness, providing guidance and praise to children. As well as the use of varied and interesting media also involve children in the activities carried out.

ABSTRAK

Kebersihan merupakan hal yang sangat penting sekali untuk diperhatikan, terutama kebersihan diri pada anak usia dini. Karena pada masa usia dini anak mengalami proses pertumbuhan dan perkembangan yang pesat maka kebersihan hal utama yang harus di perhatikan karena anak sangat mudah terkena penyakit. Hal tersebut menuntut guru untuk mampu menerapkan kebersihan diri pada anak. Penelitian ini bertujuan untuk mendeskripsikan peran guru dalam menerapkan kebersihan diri pada anak.TK Negeri Pembina Keliling Danau menjadi subyek penelitian, yaitu satu orang kepala sekolah dan 7 orang guru. Penggunaan analisis kualitatif dalam penelitian ini dengan teknik observasi, wawancara dan dokumentasi sebagai pengumpulan data. Hasil penelitian adalah guru memberikan motivasi kepada anak dalam hal menjaga kebersihan, memberikan bimbingan dan pujian kepada aank. Serta penggunaan media yang bervariasi dan menarik juga melibatkan anak dalam kegiatan yang dilakukan.
\end{abstract}

This is an open access article under the Lisensi Creative Commons AtribusiBerbagiSerupa 4.0 Internasional

(@) (1) (-)

Corresponding Author:

Penia Lisa Ogemi,

Universitas Negeri Padang

Email: ogemipenialisa@gmail.com

\section{PENDAHULUAN}

Usia dini adalah suatu perjalanan hidup yang panjang dan penting dalam hidup manusia. Karena pembentukan pondasi dan dasar kepribadian terbentuk pada usia dini, sehingga anak mendapatkan pengalaman yang sangat banyak. Pada saat ini proses pertumbuhan dan perkembangan terbentuk dengan cepat. Oleh sebab itu pada masa itulah anak dapat memperoleh stimulus secara optimal (Putri \& Eliza, 2019:1)

Usia dini menjadi salah satu tahapan usia yang bisa membentuk sistem jaringan otak pada anak sesuai dengan tingkat usia yang dimiliki oleh anak, oleh sebab itulah pada tahapan usia ini 
sering disebut sebagai masa keemasan bagi anak dan jangan terlewatkan dengan tidak memberikan stimulasi baik bagi anak (Suryana \& Delfia, 2019: 20).

Sayer, et. al. (2018) menjelaskan bahwa anak pada masa ini merupakan satu generasi penerus. PAUD akan menjadi salah satu harapan baru yang akan membentuk generasi penerus dan memiliki tingkat kualitas serta pribadi yang baik untuk menjadi penerus bangsa.

Pada tahapan usia dini kegiatan bermain merupakan salah satu media belajar bagi anak, pada tahapan usia ini kegiatan bermain juga tidak bisa terlepas dari diri anak, anak bermain dengan apapun yang ada disekitarnya, banyak hal yang bisa di pelajari dan ditemukan anak dalam kegiatan bermaian, bagaimana anak bisa bersosialisasi dengan teman dan lingkungannya, cara anak mengatur emosinya serta bagaiman anak bisa melakukan kerjasama yang baik dengan orang lain (Mulyasa 2014:166).

Bagi orang dewasa kegiatan bermain yang dilakukan oleh anak merupakan suatu hal yang sepele dan banyak membuang waktu. Namun dengan kegiatan bermainlah anak-anak dapat mengembangkan berbagai aspek perkembangan yang ada pada diri anak serta melalui kegiatan bermain pula anak mampu bersosialisasi dengan lingkungan sekitarnya.

Dengan kegiatan bermain anak akan rentan sekali terhadap kuman dan penyakit. Baik dirumah ataupun disekolah ketika bermain ataupun melakukan berbagai hal akan sangat rentan terkena penyakit atau kuman yang menempel pada diri anak. Maka dengan demikian kebersihan diri pada anak sangat utama di tanamkan sejak dini pada anak. kebersihan menjadi hal utama yang harus di perhatikan dan jika tubuh anak bersih maka aspek perkembangan dan pertumbuhan akan berkembang dengan baik. Disinilah peran guru sebagai orang yang terdekat bagi anak di sekolah dan juga merupakan contoh bagi anak, sehingga eran guru dalam mengajarkan kebersihan pada diri anak sangat penting.

Kebersihan diri merupakan sebuah tindakan yang dilakukan untuk menjaga dan memelihara kebersihan pada badan. Menurut (Potter, Perry \& Peterson, 2005) menyebutkan bahwa kebersihan pada diri merupakan salah satu cara yang paling efektif untuk mengurangi resiko terkenanya beragam macam penyekit pada diri. Beberapa cara yang termasuk dalam kegiatan menjaga kebersihan diri merupakan, mecuci tangan,mandi, memcuci rambut, menyikat gigi, memotong kuku, dan menggunakan pakain yang bersih. Agar terhindar dari penyakit dan diri tetap bersih maka semua cara tersebut harus di patuhi dan selalu di laksanakan.

Isro'in \& Andarmoyo (2012:2) menjelaskan terdapat macam-macam kebersihan diri, diantaranya : 1) kebersihan kesehatan kulit, 2) kebersihan dan kesehatan kaki, tangan dan kuku, 3) kebersihan dan kesehatan gigi dan mulut, 4) kebersihan dan kesehatan rambut, 5) kebersihan dan kesehatan mata, telinga dan hidung. Oleh sebab itulah kebersihan diri harus dijaga sedini mungkin agar kita terhindar dari beragam jenis penyakit yang diakibatkan dari kotoran yang ada pada diri. Livianti, Ali \& Yusuf (2015) tanda-tanda seseorang kurang dalam perawatan kebersihan diri, yaitu bernampilan yang tidak rapi dan memakai pakaian yang kotor,bau badan yang di akibatkan karena jarang mandi, rambut yang kotor karena tidak di cuci, tidak memotong kuku dan dipenuhi dengan banyak penyakit kulit lainnya.

Maka dari hal tersebut sangatlah penting untuk dilakukan penanaman pemahaman pada anak usia dini tentang pentingnya menjaga kebersihan diri. Hal tersebut bertujuan untuk meningkatkan kesadaran diri pada anak terkait kebersihan, karena dengan adanya pemberan pemahaman pada anak terkait kebersihan diri anak akan menjad sadar sedini mungkin terkait kebersihan diri. Alamsyah (2015) tubuh manusia yang kotor, terutama pada diri anak usia dini maka akan sangat mudah terkena penyakit, oleh sebab itulah upaya dalam mempromosikan kesehatan melalui kebersihan pada anak usia dini sangat penting untuk dilakukan.

Pemberian pemahaman tentang kebersihan diri bisa dilakukan disekolah yang dilakukan oleh guru dan dirumah bersama orang tua. Karena guru merupakan contoh yang sering ditiru oleh anak maka pemberian pehaman tentang kebersihan diri oleh guru akan mudah di tangkap oleh anak. 
Pemberian pemahaman tersebut bisa dilakukan dengan cara memberi penjelasan pada anak dan praktek yang paling sederhana terkait hal menjaga kebersihan diri seperti mencuci tangan (Reindrawati, 2020) .

Dengan demikian maka peran guru di sekolah dalam menanamkan pemahaman tentang kebersihan diri pada anak usia dini sangatlah diperlukan. Yusuf \& Sugandhi, 2011) guru merupakan salah satu kompenen yang sangat penting dalam dunia pendidikan. Orang pertama yang menjadi pengimplementasian dan penerapan dalam berbagai program di sekolah adalah seorang guru, sehingga peranan guru disekolah memiliki peran yang sangat penting dalam tercapainya tujuan pendidikan.

Peran guru disekolah dalam mengajarkan kepada anak cara menjaga kebersihan diri bisa dilakukan melalui kegiatan sehari-hari, seperti membuang sampah pada tempatnya, maka disinilah guru menjalankan perannya disekolah dalam menerapkan kebersihan pada anak, karena guru model utama disekolah maka akan ditiru oleh anak (Melati, 2012).

Peran guru dalam mengajarkan keberishan pada diri anak akan sangat berdampak bagi setiap proses perkembangan anak. karena anak akan mengikuti apa yang dilakukan oleh gurunya. Jadi agar perkembangan anak menjadi optimal dibutuhkan peran guru dalam mengajarkan kebersihan diri pada anak, karena dengan badan yang sehat akan menjadi kunci bagi kesuksesan anak. Berdasarkan penjelasan di atas maka peneliti melakukan penelitian terkait peran guru dalam menerapkan kebersihan pada anak dengan tujuan untuk mengetahui bagaimana peran seorang guru dalam menerapkan Kebersihan di TK Negeri Pembina Keliling Danau.

\section{METODE PENELITIAN}

Penulisan artikel ini menggunakan metode deskriptif kualitatif. Iskandar (2016) menjelaskan metode deskriptif adalah sebuah cara untuk memaparkan dan menggambarkan sebuah permasalahan serta dilakukan penelitian dengan harapan untuk mendapatkan tanggapan terkait dengan masalah yang mana didapat hasil dilakukan setelah kegiatan eksploratif.

Penelitian ini bertujuan untuk mengetahui peran guru dalam menerapkan kebersihan diri di TK Negeri Pembina Keliling Danau dan menjelaskan berbagai permasalahan yang terjadi di lapangan. Responden dalam penelitian ini adalah 1 orang kepala sekolah dan 7 orang guru TK Negeri Pembina Keliling Danau.

Prosedur dalam kegiatan penelitian diawali dengan dengan pengumpulan data terkait peran guru dalam menerapkan kebersihan diri di TK Negeri Pembina Keliling Danau melalui kegiatan observasi dimana peneliti melakukan kegiatan observasi di TK Negeri Pembina untuk melihat bagaimana peran guru dalam menerapkan kebersihan pada anak, selanjutnya kegiatan wawancara yang peneliti lakukan pada 7 orang guru dan 1 orang kepala sekolah. Menanyakan apa saja yang merekal lakukan dalam hal menerapkan kebersihan diri pada anak dan bagaimana kendala yang terjadi dalam penerapan tersebut dan dokumentasi yang menjadi bukti kegiatan penelitian peneliti yang diambil dalam bentuk gambar, video dan rekaman suara.

Dalam penyajian data, penulis mengambil kutipan dari berbagai referensi dan ianalisis dengan menyertakan sumber kemudian diringkas untuk setiap topik yang telah dianalisis. Hal ini tentunya dengan pemikiran kritis dan analisis informasi secara mendalam.

\section{HASIL PENELITIAN DAN PEMBAHASAN}

Kebersihan diri merupakan hal yang sangat penting untuk di lakukan terlebih pada anak usia dini, karena pada masa usia dini tahapan perkembangan anak perkembang dengan pesat maka anak yang sehat akan berkembang dengan baik. maka peran guru dalam menerapkan kebersihan sangan penting dilakukan. Dalam menerapkan kebersihan diri di TK Negeri Pembina Keliling Danau banyak sekali hal yang dilakukan oleh guru agar anak terbiasa dalam menjaga kebersihan diri. 
Hasil wawancara yang peneliti lakukan dengan kepala sekolah dan guru pada TK Negeri Pembina Keliling Danau. Dijelaskan bahwa terkait pemahamn mengenai kebersihan diri kepala sekolah dan guru sangat mengerti tentang apa itu kebersihan dan memiliki pemahaman yang baik terkait pentingnya kebersihan diri dan cara dalam menjaga kebersihan diri, salah satunya pada anak usia dini. Salah satu cara yang dilakukan adalah melalui kegiatan praktek langsung karena anak akan sangat mudah memahami jika guru memberikan contoh langsung kepada anak juga mendampingi anak secara langsung dalam hal melakukan kebersihan diri. Dan yang paling utama juga memberikan selalu semangat dan motivasi pada anak, karena melalui motivasi yang diberikan oleh guru maka anak akan semangat dalam melakukan berbagai hal salah satunya menjaga kebersihan diri.

Berdasarkan wawancara yang telah dilakukan dengan pihak TK Negeri Pembina Keliling Danau dengan 1 orang Kepala sekolah dan 7 orang guru terkait peran guru dalam menerapkan kebersihan diri pada anak berdampak sangat positif dan mengalami keberhasilan yang meningkat, setelah anak di ajarkan secara rutin terkait menjaga kebersihan diri. Sehingga anak menjadi terbiasa dalam menjaga kebersihan diri melalui bantuan dari para guru yang selalu membimbing dan memberikan arahan kepada anak dalam menjaga kebersihan diri dan memberikan peningkatan yang baik dalam pengetahuan anak dalam menjaga kebersihan dan merawat diri.

Kemudian, berdasarkan kegiatan observasi yang telah peneliti lakukan selama 5 kali pertemuan, peneliti temukan bahwa semangat guru dalam memberikan pemahaman tentang kebersihan diri pada anak sangat tinggi. Penggunaan media yang asli dan menarik menjadi daya tarik tersendiri bagi anak sehingga anak menjadi antusias dan semangat melakukan kegiatan kebersihan diri dan membuat anak semangat dalam kegiatan pembelajaran.

Kegiatan dalam menerapkan kebersihan diri pada anak dilakukan dengan kegiatan yang bervariasi dan menarik sehingga anak tidak merasa bosan dan antusias selalu dalam melakukan kegiatan kebersihan.

Jadi dari hasil wawancara dan obeservasi selama 5 kali yang peneliti lakukan di TK Negeri Pembina ditemukan bahwa dampak positif dari kegiatan yang diajarkan oleh guru dalam menjaga kebersihan diri adalah anak selalu mandi pagi sebelum kesekolah, menggosok gigi dan menggunakan pakain yang bersih, mencuci tangan sebelum dan sesudah makan dan juga setelah melakukan kegiatan. Kegiatan tersebut dilakukan anak dengan sendirinya melalui arahan guru tetapi tidak ikut langsung dalam kegiatan tersebut, hal itu dilakukan agar anak terbiasa melakukan kegiatan kebersihan dengan sendiri.

Tanggung jawab yang besar yang di miliki oleh guru dalam mendidik dan mencerdaskan anak bangsa. Karena tugas seorang guru begitu mulia dan juga guru mendapatkan posisi yang terhormat didalam masyarakat. Memiliki pribadi yang baik adalah harapan semua guru pada diri anak, karena tidak ada guru yang menginginkan anak didiknya menjadi sampah dalam masyarakat (Niati, 2019).

Asmani (2011) menjelskan bahwa seorang guru hendaknya bisa memberikan dorongan yang baik kepada anak agar anak aktif dalam belajar, memberikan motivasi akan berdampak positif bagi perkembangan anak. Hal yang paling mendasarkan yang harus ditanamkan oleh guru sejak sedini mungkin pada anak adalah bagaimana cara dalam menjaga kebersihan diri anak. Karena anak dalam tahapan proses belajar dalam menjaga diri maka akan sangat rentan sekali bila terkena penyakit.

Peran penting yang utama dilakukan oleh pendidik anak usia dini adalah dalam melihat tingkat perkembangan dan pertumbuhan yang ada pada siawa. Karena sebab tersebut jika seorang pendidik PAUD harus mempunyai kemampuan yang baik. guru juga memiliki peran untuk selalu meningkatkan profesionalisme nya dalam profesinya terutama dalam PAUD. Guru PAUD yang seperti inilah yang akan meningkatkan tingkat profesional pendidik, sebagai penggerak para pendidik lainnya menuju lebih baik lagi. Kemempuan guru PAUD tersebutlah yang dikatakan sebagai pendidik yang paham akan perubahan di abad 21 (Muhson, 2004: Tanang \& Abu, 2014). 
Dalam mengajarkan arti kebersihan pada diri anak, peran guru sebagai orang yang paling terdekat dengan anak di lingkungan sekolah sangat di perlukan Sardiman (2011) peran guru sebagai pengajar pada anak dalam artian mengajarkan banyak hal kepada anak salah satunya mengajrkan anak dalam menjaga kebersiham, sebagai mediator guru menjadi penengah dalam kegiatan siswa, dan juga sebagai motivator sangat di perlukan bagi anak dalam memberikan motivasi. Maka sangatlah di perlukan peran guru dalam memberikan pemahaman tentang kebersihan pada anak.

Berdasarkan data yang telah disimpulkan di atas maka guru sangat dibutuhkan dalam mengajarkan kebersihan kepada anak. Dengan adanya bantuan dari guru maka anak akan sangat merasa termotivasi dalam melakukan kegiatan menjaga kebersihan diri. Sebagi seorang tenaga pendidik yang akan memberikan banyak ilmu kepada anak dan juga akan menghasilkan anak didik yang berkualitas dan berpendidikan (Bogor, 2019). Jadi sudah sewajarnyalah peran guru dalam menerapkan kebersihan diri pada anak, karena kebersihan merupakan hal terpenting pada diri anak. Itu yang telah dilakukan oleh tim majelis guru TK Negeri Pembina Keliling Danau dalam mengajarkan kegiatan kebersihan diri pada anak.

\section{KESIMPULAN}

Dari penjelasan yang telah peneliti jelaskan jadi peranan guru dalam mengajarkan kebersihan pada anak di lembaga TK Negeri Pembina Keliling Danau sangat penting karena dengan peranan guru dalam menerapkan kebersihan diri pada anak menjadikan anak yang perhatian akan kebersihan pada diri. Kebersihan ditanamkan guru melalui hal-hal kecil agar nantinya anak akan selalu tebiasa dalam menjaga kebersihan dan terhindar dari berbagai jenis penyakit. Pemberian motivasi kepada anak agar anak mau untuk selalu menjaga kebersihan diri. Penggunaan media yang menarik dan perencanaan kegiatan yang matang serta melibatkan langsung anak dalam kegiatan kebersihan, karena dengan hal tersebut akan menumbuhkan semangat anak dalam menjaga kebersihan diri. Menggunakan bahasa yang jelas dan mudah di mengerti oleh anak sehingga anak akan lebih mudah mengaplikasikan apa yang di jelaskan oleh guru. Ketika anak mengetahui apa itu kebersihan diri dan apa saja dampak dari kurangnya dalam menjaga kebersihan diri maka kemauan anak akan semakin tinggi dalam menjaga kebersihan.

\section{DAFTAR PUSTAKA}

Alamsyah. (2015). Ini Pentingnya Ajari Kebersihan Pada Anak Sejak Dini,https://www.republika.co.id/, diakses tanggal 1 Desember 2021

Asmani, Jamal Ma'mur. (2011). Buku Panduan Internalisasi Pendidikan Karakter di Sekolah. Yogyakarta: Diva Press.

Bogor, K. (2019). Pentingnya Peran Guru dalam Pendidikan. Bogor: Kampus kita; http://koranbogor.com/berita/kampus-kita/pentingnya-peran-guru-dalampendidikan/.

Iskandar, J. (2016). Metode Penelitian Sosial. Bandung: Puspaga. Isro'in, Laily \& Andramoyo, Sulistyo. (2012). Personal Hygiene. Yogyakarta: Graha Ilmu.

Livianti, Devi, Ali, Muhammad \& Yusuf, Abas. (2015). Peran Guru Terhadap Kebersihan Diri Anak Usia 4-5 Tahun Di Paud Sutitah Soedarso 1 Desa Jungkat. Jurnal pendidikan dan pembelajaran khatulistiwa. Vol 4, No. 4

Melati, Risang. (2012). Kiat Sukses Menjadi Guru PAUD yang Disukai Anak-Anak. Yogyakarta: Araska.

Muhson, A. 2004. Meningkatkan Profesionalisme Guru: Sebuah Harapan. Jurnal Ekonomi \& Pendidikan, 2(1). https://doi.org/10.21831/jep.v1i2.665

Mulyasa. (2014). Manajemen PAUD. Bandung: PT Remaja Rosdakarya 
Niati, Wika. (2019). Peran Guru Dalam Menstimulasi Perkembangan Bajsa Anak Pada Kelompok B Usia 5-6 Tahun Di TK Darma Wanita Kab. Seluma. Al Fitrah Journal Of Early Childhood Islamic Education. Vol. 3 No. 1

Perry, Peterson, Potter. (2005). Buku Saku Ketrampilan Dan Prosedur Dasar. Jakarta: Widya Medika Java Books Indonesia

Putri, Syamsurandi Eka \& Eliza, Delfi. (2019). Peningkatan Kerjasama Anak Melalui Cerita Minangkabau Di Taman Kanak - Kanak Nurul Haq Sasak. Inovtech. Volume 01 Number 02. Issn Online 2715-2049

Reindrawati, Dian Yulie. (2020). Pembiasaan Menjaga Kebersihan Sejak Usia Dini (Pengabdian Pada Murid TK Bintang Kecil Surabaya). Jurnal Anadara Pengabdian Kepada Masyarakat. Vol. 2, No. 1

Sardiman. (2011). Interaksi dan Motivasi Belajar Mengajar. Jakarta: PT Raja Grafindo Persada.

Sayer, I. M., Kristiawan, M., \& Agustina, M. (2018). Fairy Tale as a Medium for Children's Character Cooperation Building.Al-Ta lim Journal,25(2),

Suryana, Dadan \& Delfia, Eva. (2019). Implementation Of Children's Numerical Skill Learning Activity In Early Childhood Education. Atlantis Press. Advences In Social Sclence, Education And Humanities Research. Volume 449

Tanang, H., \& Abu, B. 2014. Teacher Professionalism and Professional Development Practices in South Sulawesi, Indonesia. Journal of Curriculum and Teaching, 3(2), 25-42. 